\title{
Nasal dorsum fistula
}

INSERM

\section{Source}

INSERM. (1999). Orphanet: an online rare disease and orphan drug data base. Nasal dorsum fistula. ORPHA:141219

A rare otorhinolaryngological malformation characterized by the presence of a dermoid cyst, located on the dorsum of the nose, which presents a fistula, often extending to the intracranial region. Patients present a firm, slow-growing mass, which contains skin and dermal elements (including hair follicles and sebaceous glands), that do not transilluminate or compress, and may be associated with intermittent or chronic discharge of sebaceous material, soft tissue and skeletal deformity, and local infection. Meningitis, convulsions and cerebral abcess may be observed if intracranial extension exists. 